\title{
LINKS BETWEEN THE LEVEL OF LOCAL AND REGIONAL DEVELOPMENT - PROBLEMS OF MEASURING
}

\author{
Mieczyslaw Adamowicz ${ }^{1}$, professor; Mariusz Pyra, MA $^{2}$ \\ ${ }_{1,2}$ Pope John Paul II State School of Higher Education in Biala Podlaska
}

\begin{abstract}
While conducting an assessment of development in territorial systems, two significant issues have been detected of theoretical and practical nature. These include the issue of measuring the level of this development and the distinction, or rather a connection between a regional and local development. Regional development does not constitute the sum resulting from the level of development of local systems, whilst the results of research on development in local systems have some direct connections with the level of regional development. One may assume that especially the development of larger cities in the region and the spatial systems linked to them ought to be similar to the development of the entire region. Within the article, the authors have analysed the links between the development of Lublin voivodeship and the level of the three cities with poviat rights from the area of the voivodeship including the three country districts forming the surroundings of these cities.
\end{abstract}

Keywords: local development, regional development, district cities, development measures. JEL code: C80, P48, R58.

\section{Introduction}

Practical dimensions of the level of regional development bearing in mind the concept of sustainable development is a seemingly easy task. The analysis of works of other researchers, dealing with practical aspects of measurement of the regional development or the local one (Churski 2005, Wojcik 2014; Wozniak 2005; Brol \& Raszkowski 2011), clearly reveal in practice lack of a uniform diagnostic tool. Theories on regional development or economic aspects of relations within the local economy of the regions create a common platform for all research works in this scope. Due to this reason, on the one hand, one may observe that the occurring differences in approach of individual researchers to the practical measurement still fit into the same theoretical frameworks. On the other hand, also the tendency to reach for a methodology assumed i.e. in the programmes of regional development of individual voivodeships or the strategies of local development is visible. The evaluation of these programmes occurs normally by means of many different meters. However, also in this particular scope one may encounter elaborations devoted to a large degree to verification of usefulness of these meters (Krok-Czyz Tomaszewski, Wysocka \& Zembaty, 2009). These elaborations clearly reveal that the assumed by Marshal Offices, city councils and communal councils as well as poviat councils meters related to specific actions and targets are not of universal nature. Many of them turn out to be useless or too costly to be gathered and analysed. This triggers a number of methods of measurement of regional and local development and the models. The accepted manner of measurement ought to serve reaching the assumed research objectives. The purpose of the article is to define and assess the links between the development of local systems and the development of the entire region. Research was carried out on the example of three cities with poviat rights and three country districts surrounding these cities, which form the basis of the three subregions of the Lublin voivodeship.

\section{Research materials and methods}

While testing regional development, it is assumed that it concerns the entire Lublin voivodeship. Whilst, when we analyse the local development, in accordance with the practice of functioning of the 
policy of local self-government units, we speak of cities, communes and poviats (potentially cities on poviat rights). This stems from the binding in Poland three-tier territorial-administrative division (Szewczuk, Kogut-Jaworska \& Ziolo, 2001). The analysis of data of the voivodeship office concerning the regional development - data of the Lublin voivodeship, as well as the local development -data of the poviats and poviat cities will run similarly: Biala Podlaska, Chelm and Zamosc representing municipalities.

Striving to obtain such a precise mapping of the real development of tested units, whilst at the same time maintaining transparency of the measurement itself and the result involve the necessity to accept certain compromises. These compromises cover above all the necessity to limit the numbers of analysed variables (thus, factors which stimulate and dissimulate local and regional development). Second of all, it is necessary to use aggregate meters. Thirdly, the number of variables presenting the state of regional and local development in a given area, personalized in the form of an aggregate meter, must be rational. Fourthly, while attempting to compare between one another the level of regional development and the local one it is necessary to apply the same method of calculating the aggregate meter for all territorial units.

Within the analysis, data disclosed by the Central Statistical Office, which gathers and processes the most significant data characteristic for multiple fields and areas of social-economic life both for the county and the internal territorial units, were used. It is assumed that CSO data ensure sufficient credibility and completeness of data and the necessary information. One must however note that data at disposal of CSO are not complete. This concerns more the data used for the purpose of local rather than regional level. The period assumed for the analysis covers years 2004-2013, thus the period of 10 years, whilst it is a period directly after the accession of Poland into the European Union. Practical consequences stemming from this fact are visible in the form of striving for harmonisation of methodology of CSO and Eurostat statistics. On the one hand this reflects the discrepancies in data delivered by Eurostat and CSO, on the other hand, explains why in case of some data in the analysed period of 10 years methodology of their storage and processing changed. Provided that the above issues are to be the subject of entirely different and wider consideration, then it is significant that data provided by CSO in some cases will not cover all the years or levels covered by the analyses (that is city, poviat, voivodeship). This leads to the necessity of accepting subsequent compromises consisting of, among others, accepting the values of some meters for the city and poviat on the same level. One must underline though that upon applying data from CSO, measurement of development at the local level (city and poviat) in some areas is not fully precise. Removal of this flaw would require supplementing data provided by CSO with own field research and the analysis of primary sources. Within the accepted concept of the article, such actions cannot be justified.

The key issue of the authors' own research methodology are the structures of aggregates. The general concept of research accepts an assumption that regional development or the local one may be measured by performing measurements in the following dimensions by means of the following diagnostic variables:

1) Labour market - situation on the labour market reflected by 6 indicators ( 2 of stimuli nature and 4 being the destimulants);

2) Society - reflects the total population on a given area including its economic situation (10 stimulants and 3 destimulants);

3) Economic situation of the households - reflects the resources of households and their members ( 6 stimulants and 1 destimulant); 
4) Education - reflects the situation in the region or poviat concerning a widely understood educational activity and perspectives in that region (10 stimulants);

5) Enterprises - reflects a real image of the situation of entrepreneurs on the local or regional market (7 stimulants and 2 destimulants);

6) Research and development and innovation - indicators reflecting general level of innovation and condition of the sector related to the research and development works (11 stimulants);

7) Infrastructure and environment - general grasping of basic resources of infrastructural nature, available or used by entities and society on a given area and the state of natural environment ( 8 stimulants).

The above presented diagnostic variables are the selected variables for individual measurements subjected to research. These are not of course all the variables available or possible for measuring, characterizing a given area. Part of the above indicated data is available in CSO bases solely at the level of voivodeships. Their choice was made post an initial analysis of availability of data and their information value. In several cases, despite unavailability of data for the entire period covered by the analysis, data have not been excluded from a given area - it stemmed from the lack of availability of alternative data. However, resigning from considering the level of GDP was not purposeful, since "GDP itself does not carry a direct information on improvement of environment of the functioning of entities in the region". One must also note that due to the incompleteness of data bases of CSO in the areas selected for research, in case in some analysed variables, a certain inconsistency of data occurs. The example may be the income at disposal of a household with consideration of their sources. In this case data were not available in a division considering the level of detail envisaged by the carried out own elaboration (that is on the poviat and city level). Therefore, identical values indicated by CSO for the Lublin voivodeship were accepted for all the analysed levels of territorial division. Moreover, in case of lack of some data for the entire period covered by the research, their estimated approximation was made or values of aggregate for a given year were omitted in calculations.

The above stated variables were subjected to dynamics analysis, first however subjecting them to the process of standardization. This stems directly from the accepted concept of aggregate meter (Kompa 2009). The postulated construction of aggregate meter fulfils all the assumptions standing before this type of meter: universal nature, availability, economy and interpretability. Moreover, construction of the meter has been known in Poland since 1968, when it was presented within Przeglad Statystyczny (Hellwig 1968). It was thus assumed that the synthetic measure of development in individual dimensions will take the form (for each of the dimensions):

$$
S M R_{\mathrm{it}}=1-\frac{q_{\mathrm{it}}}{\overline{q_{\mathrm{t}}}+2 * S_{q t}}
$$

where:

$\mathrm{S}_{\mathrm{qt}}$ - standard deviation calculated according to the following pattern:

$$
S_{q t}=\sqrt{\frac{1}{n} \sum_{i=1}^{n}\left(q_{i t}-\overline{q_{t}}\right)^{2}}
$$

$\overline{q_{t}}$ - average value

$\mathrm{q}_{i t}$ - distance of the $\mathrm{i}$-th object from the accepted pattern, appointed by means of Euclidean metric on the basis of standardized variables: 


$$
q_{\mathrm{it}}=\sqrt{\frac{1}{k} \sum_{j=1}^{k}\left(z_{j t}^{i}-z_{j t}^{0}\right)^{2}}
$$

$z_{j t}^{0}, z_{j t}^{i}$ - values of variables adequately describing the pattern and the i-th object

Research post standardization, carried out according to the following pattern:

$$
z_{j t}^{i}=\frac{z_{j t}^{i}-\bar{x}_{j t}}{S_{j t}^{X}}
$$

Such assumed synthetic meter assumes values within the range $[0 ; 1]$ - the closer to unity its value in a given area, the larger probability of accepting the pattern characterized by the assessed area.

The above actions and analyses have been conducted by means of STATISTICA software by StatSoft.

Amongst all the available data in public data statistics, diagnostic data have been selected which have been identified and classified within 7 areas, in one of the two groups: stimulants (s) - factors with positive impact on a broadly-understood development and destimulants (d) - factors significantly hindering the development of a given region:

- Education - factor of primary school enrolment rate net (S), factor of lower secondary school enrolment rate net (S), factor of vocational school enrolment rate net (S), factor of high school enrolment rate net. Net (S), number of primary schools (S), number of lower secondary schools $(S)$, number of high schools (S), number of universities (S), number of students (S), number of university graduates $(\mathrm{S})$.

- Labour market - total unemployment in the region (D), unemployed above 1 year total (D), unemployed with higher education (D), unemployed with high school and second degree education (D), created work places (voivodeship) [thousand] (S), liquidated work places (voivodeship) [thousand] (S).

- Economic situation of households - income at disposal per 1 person in a household (S), income at disposal in a household per 1 person from contract work (S), income at disposal in a household per 1 person in a household (S), income at disposal in a household per 1 person from selfemployment (S), income at disposal in a household per 1 person from social benefits (D), expenditure for education per 1 person in a household per month [PLN] (S), average monthly gross remuneration (S).

- Research, development and innovation - employment in R\&D sector in total (voivodeship) (S), employment in R\&D sector in total per 1 thousand of professionally active (voivodeship) (S), internal expenditure for R\&D [PLN million] (S), internal expenditure for R\&D per 1 inhabitant [PLN] (S), internal expenditure for R\&D per 1 employed [PLN] (S), internal expenditure for R\&D in the sector of higher education [PLN] (S), internal expenditure for R\&D [PLN] (S), external expenditure, -Funds from PAN [PLN thousand], average share of innovative enterprises in total number of enterprises (voivodeship) [ \%] (S), expenditure for innovative activity per 1 person professionally active [PLN] (S), share of revenue from sale of innovative products in total revenue from sale [\%] (S).

- Infrastructure and environment - use of electricity in total [GWh] (S), use of electricity industry (voivodeship) [GWh] (S), use of electricity household (voivodeship) [GWh] (S), surfaced roads per 10 thousand persons $[\mathrm{km}](\mathrm{S})$, contaminations sustained in relation to the emitted ones - 
particulate [\%] (S), number of sewage treatment plant of all types - industrial (S), number of sewage treatment plants - communal (S), exploited railway routes [km] (S).

- Enterprises - entities entered into the register of REGON per 10 thousand persons (S), newly registered entities in the region REGON per 10 thousand persons (S), entities removed from the register REGON per 10 thousand persons (D), share of entities removed in the general number of entities in the region REGON [ \%] (D), entities newly registered per 1 thousand persons at the working age (S), average monthly remuneration in sections $A+B(S)$, average monthly remuneration in sections $C+D+E(S)$, average monthly remuneration in section $K(S)$, average monthly remuneration in section $\mathrm{M}(\mathrm{S})$.

- Community - $M$ total (S), $K$ total (S), $m$ at pre-working age (S), $K$ at pre-working ate (S), $M$ at working age (S), $K$ at working age (S), $M$ at post-working age (D), $K$ at post-working age (D), number of households $(S)$, number of flats $(S)$, registrations in total $(S)$, registration notices (D), total net migration rate (S).

Assessment of the level of regional and local development

When applying the previously described model of assessment of local and regional development, based on the aggregate meter, an assessment of development of individual spatial entities covered by the research was performed. By analogy, as in case of the analysis of dynamics of changes in factors of local development, an assessment of local and regional development in year 2004 and 2013 was carried out (beginning and end of the research period). Data referring to the Masovia voivodeship and the city of Warsaw with poviat rights were assumed as a pattern. The choice of pattern is not coincidental. The Masovian voivodeship and, in particular, the city of Warsaw and the fastest and most dynamically developing city in the region and within the geographic area. Therefore, one may treat data describing this voivodeship and poviat as a pattern, which other regions of the country should follow. The graph below presents the results of such comparison. One must however bear in mind that both the city of Warsaw as well as the entire Masovia voivodeship are on a privileged position in many different terms. The applied methodology is not based on the direct comparison of the researched objects with the pattern, but only after data standardization. Thanks to the standardization, differences in the level of size disappear and changes in these levels and relations between the analysed data are clearly visible. Application of the above described aggregate meter allows to compare the situation in given areas (or comprehensively as it will be shown below) between the tested objects and the pattern. This is not a direct comparison of absolute volumes, but rather a comparison which allows for specifying the relative position with reference to the pattern (or rather standardized variable values describing the pattern). This must be remembered at all times while performing the analysis of results of the assessment of development of the Lublin voivodeship and the poviats and cities covered by the analysis.

As one may notice on the graph below, the Lublin voivodeship, upon the use of the described aggregate meter in 2004 obtained mark 0.8260. In other words, its level of development with regards to its size and setup of internal factors (thus, in the context of size of diagnostic data describing it) was assessed at the level of $83 \%$ of the status which was reached by the pattern with regards to its size and setup of internal factors (pattern). The Lublin voivodeship, having at its disposal the resources and attributes of the Masovia voivodeship, would reach approx. $83 \%$ of its level. One ought to underline yet again that this is a relation-based measurement which reflects in a certain 
sense the potential (of a given voivodeship) and the degree of its use in relation to the use of its potential by the accepted pattern.

An analogue assessment of the state of development of the Lublin voivodeship in 2013 reveals that the voivodeship reached the value of aggregate meter equal to 0.8180 . One should interpret this as a drop of a degree of development of the voivodeship in the context in which it has been assessed (in comparison to the pattern). This means that the value of aggregate meter, lower than in 2004 , may be caused by: the pattern was characterized by a larger efficiency and growth dynamics in the years between the assessed periods and/or the pattern developed more effectively than the tested voivodeship; and/or the tested voivodeship experienced a slowdown of development. All three above causes seem to be probable. One must also indicate that a weak plane of the Lublin voivodeship both in 2004 and in 2013 was noted in the area of enterprises.

Precise values of SMR meter towards individual dimensions have been presented in table 1 and in table 2. Lack of data in the area of research and development/ innovation at the local level has been noticed. These data were available only for the regional level. Also lack of total meter for the Bialski poviat in 2004 was detected.

Table 1

Value of SMR meter in individual dimensions and value of total meter in 2004

\begin{tabular}{|l|c|c|c|c|c|c|c|}
\hline \multirow{2}{*}{\multicolumn{1}{c|}{ Area }} & \multicolumn{7}{c|}{ Territorial unit } \\
\cline { 2 - 9 } & $\begin{array}{c}\text { Lublin } \\
\text { voivodeship }\end{array}$ & $\begin{array}{c}\text { Bialski } \\
\text { poviat }\end{array}$ & $\begin{array}{c}\text { Chelmski } \\
\text { poviat }\end{array}$ & $\begin{array}{c}\text { Zamojski } \\
\text { poviat }\end{array}$ & $\begin{array}{c}\text { City of } \\
\text { Biala } \\
\text { Podlaska }\end{array}$ & $\begin{array}{c}\text { City of } \\
\text { Chelm }\end{array}$ & $\begin{array}{c}\text { City of } \\
\text { Zamosc }\end{array}$ \\
\hline Labour market & 0.84 & 0.99 & 0.83 & 0.83 & 0.58 & 0.84 & 0.83 \\
\hline Community & 0.61 & 0.82 & 0.76 & 0.80 & 0.71 & 0.50 & 0.79 \\
\hline $\begin{array}{l}\text { Economic situation of } \\
\text { households }\end{array}$ & 0.74 & - & -1.43 & 0.79 & 0.68 & -0.13 & 0.72 \\
\hline Education & 0.85 & - & 0.72 & 0.76 & 0.55 & 0.70 & 0.55 \\
\hline Enterprises & 0.01 & - & 0.72 & 0.65 & 0.69 & 0.71 & 0.69 \\
\hline $\begin{array}{l}\text { Research and } \\
\text { development/ } \\
\text { innovation }\end{array}$ & 0.79 & - & - & - & - & - & - \\
\hline $\begin{array}{l}\text { Infrastructure and } \\
\text { environment }\end{array}$ & 0.79 & - & 0.79 & 0.74 & 0.66 & 0.86 & 0.46 \\
\hline Total meter & 0.83 & - & 0.80 & 0.83 & 0.67 & 0.83 & 0.80 \\
\hline
\end{tabular}

Source: authors' elaboration

Table 2

Value of SMR meter in individual dimensions and value of total meter in 2013

\begin{tabular}{|l|c|c|c|c|c|c|c|}
\hline \multirow{2}{*}{\multicolumn{1}{c|}{ Area }} & \multicolumn{7}{c|}{ Territorial unit } \\
\cline { 2 - 9 } & $\begin{array}{c}\text { Lublin } \\
\text { voivodeship }\end{array}$ & $\begin{array}{c}\text { Bialski } \\
\text { poviat }\end{array}$ & $\begin{array}{c}\text { Chelmski } \\
\text { poviat }\end{array}$ & $\begin{array}{c}\text { Zamojski } \\
\text { poviat }\end{array}$ & $\begin{array}{c}\text { City of } \\
\text { Biala } \\
\text { Podlaska }\end{array}$ & $\begin{array}{c}\text { City of } \\
\text { Chelm }\end{array}$ & $\begin{array}{c}\text { City of } \\
\text { Zamosc }\end{array}$ \\
\hline Labour market & 0.84 & - & 0.79 & 0.78 & 0.59 & 0.80 & 0.81 \\
\hline Community & 0.63 & 0.78 & 0.49 & -0.06 & 0.66 & 0.62 & 0.52 \\
\hline $\begin{array}{l}\text { Economic situation of } \\
\text { households }\end{array}$ & 0.79 & 0.53 & 0.66 & 0.77 & 0.61 & 0.78 & 0.44 \\
\hline Education & 0.84 & - & 0.83 & 0.83 & 0.58 & 0.58 & 0.54 \\
\hline Enterprises & -0.17 & 0.65 & 0.64 & 0.23 & 0.59 & 0.30 & -0.26 \\
\hline $\begin{array}{l}\text { Research and } \\
\text { development/ } \\
\text { innovation }\end{array}$ & 0.63 & - & - & - & - & - & - \\
\hline $\begin{array}{l}\text { Infrastructure and } \\
\text { environment }\end{array}$ & 0.66 & 0.96 & -0.12 & 0.71 & 0.28 & 0.63 & 0.24 \\
\hline Total meter & 0.82 & 0.89 & 0.82 & 0.85 & 0.62 & 0.85 & 0.85 \\
\hline
\end{tabular}


Essentially, in case of the majority of tested territorial systems the aggregate meter in 2013 assumed higher values than the one in 2004. The relations between the level of development in the local systems and the level of the entire region were formed in a diverse manner. In 2004, the total indicators of local development were equal or below the level of indicators of the voivodeship growth. Whilst, in 2013 the growth indicators of the majority of poviats and cities started to be higher than the level of the regional development. In that particular year weak parameters of growth within the Chelmski poviat and the city of Biala Podlaska were reported. It is worth to carry out an analysis thus, applying the same methodology, calculating the aggregate meter for individual, distinguished dimension of regional and local development. However, an obstacle arises here, stemming from the fact of applying standardization of further stems, assumed by the accepted methodology. Hence, in case of the Bialski poviat in 2004 (both at the level of the meter of total assessment as well las the partial meters in several dimensions) one cannot carry out a designation of values of aggregate meter. Value $q_{i t}$ would require establishing square root (thus an even one) from a negative number, which is impossible from mathematical point of view. Therefore, in case of the Bialski poviat in 2004 the values were not considered in the table and it will not be subjected to any detailed analysis. This issue did not occur in the case of the remaining poviats and cities and in case of the assessment of the Bialski poviat in year 2013. One must thus consider that the accepted methodology is not perfect, which however does not compromise the possibility of applying and obtaining correct results for the systems for which it was possible to carry out the calculations. The results of these calculations have been indicated on the graphs. The obtained results of the analysis allow to specify, next to the dynamics of changes, also the relations between the level of local development and the regional one.

The City of Biala Podlaska was in 2004 characterized by a relatively small but balanced degree of development (use of potential) in all six of the detailed areas. Whilst, in 2013 this development was not so balanced. A delay in development in the area of infrastructure and environment was clearly visible, as well as most likely, even though to a lesser degree, in the area of community and economic situation of the households. Only in the scope of education, the city reached a higher value than that in 2004 in terms of aggregate meter. In light of weak development of the cities in 2013, a high degree of development of the surrounding Bialski poviat is transparent. Detailed data concerning this poviat have been presented in Table 1 and in Table 2.

On the one hand, in case of the Chelmski poviat a clear disproportion may be noticed. In 2004, economic situation of the households was very badly assessed, whilst in 2013 it significantly improved. On the other hand, in the area of infrastructure and environment, as well as in the social area, the assessment in 2013 was subject to a radical deterioration. In the remaining dimensions of assessment, the results were very similar or they were subject to a minor drop. In case of the city of Chelm the situation was similar. In this area the situation of households significantly improved. The city of Chelm also improved its assessment in the area of community, however, in the remaining areas the value of aggregate meter often reached lower levels than in 2004. Substantial worsening occurred in the area of enterprises which means that Chelm did not develop dynamically and in a balanced way.

The general indicator of development of the city of Zamosc and the Zamojski poviat was subject to a slight improvement. But these territorial units are an exceptional case of large imbalance in development. In 2004 the Zamojski poviat may be considered as rather sustainable in its development and use of potential in all six dimensions. Whilst, in 2013 certain growth disproportions appeared. The value of aggregate meter was at a similar level. Whilst it is clear that the weaker 
development in the area when it comes to the enterprises was accompanied by almost no development in the area of community.

The city of Zamosc is also characterized by developmental disproportions. In fairness, the total meter decreased but negative decrease tendencies are noticeable in the area of enterprises and community.

\section{Conclusions}

1) The Lublin voivodeship was in 2013 characterized by a rather low level of development, which may stem from the fact of failure to use the chances and potential. The carried out analysis revealed that the Lublin voivodeship does not keep up in the right degree with the development of the pattern voivodeship - the Masovia voivodeship. As a consequence, a relative assessment of the level of development of the Lublin voivodeship in 2004 was slightly better than one in 2013. These results are however no surprise, since Lublin voivodeship was in 2012 at the $11^{\text {th }}$ place among the poorest regions in the entire EU and in the first 3 poorest regions in Poland. In the context of this information, the relatively weak results of the Lublin voivodeship is no surprise. What is more, a detailed analysis combined with an assessment (upon applying the same meter structure) of the selected for testing poviats and cities revealed large disproportions among these areas and the dimensions subjected to the assessment. The majority of territorial systems, apart from the city of Biala Podlaska, obtained generally slightly higher grades than they did in 2004. Furthermore, the analysis revealed the occurrence of large disproportions and even delays suggesting the possible collapse in some development areas. This means that the processes related to regional and local development take place on the tested area, however, they are of diverse nature (from the perspective of dimensions subjected to the assessment) and they seem to be non-coordinated. This is confirmed, above all, by a delay in infrastructure growth, which substantially hinders the development in the remaining areas, weakening through this the impact of actions undertaken by local authorities and the target programmes. Differences between the situation of the assessed cities are also visible which means that each of them has used their potential in a different way and attempts to find itself in the overall economic situation of the entire voivodeship. Essentially, one must note that the present situation has some substantial negative effects in the area of local community (especially when it comes to migration and community structure). Whilst, a slight effect of city polarization among the cities which obtained better assessments than the entire poviat in some areas is visible.

2) The measurement of regional and local development, considering the targets and ideas of sustainable development is a difficult task and one that involves multiple issues. Of course, the necessity to carry out certain choices as to the meters of individual areas and layers of development seems obvious. One cannot also avoid certain simplifications and omissions of less important factors. Nevertheless, it is still possible to agree the level of regional development and compare these results with other regions. A similar situation takes place in case of the local level, but one must bear in mind the necessity of maintaining consistency in applying the selected meters and methods of measurement.

\section{Bibliography}

1. Brol R., Raszkowski A. (2011), Problemy rozwoju regionalnego. [Problems of Regional Development], Wroclaw University of Economics, Wroclaw.

2. Churski p. (2005), Nowe mechanizmy programowania rozwoju regionalnego w Polsce na przykladzie wojewodztwa kujawsko-pomorskiego. [New Mechanisms for Programming Regional Development in Poland 
on the Example of the Kujawsko-Pomorskie Voivodeship], European Teaching, Yearbook, Smolensk University of Humanities, Wloclawek - Smolensk.

3. Hellwig Z. (1968), Zastosowanie metody taksonomicznej do typologicznego podzialu krajow ze wzgledu na poziom ich rozwoju oraz zasoby i strukture kwalifikowanych kadr. [Application of the Taxonomic Method to the Typological Division of Countries Based on the Level of Their Development and the Resources and Structure of Qualified Personel], Statistical Review, no. 4, Torun.

4. Kompa K. (2009), Budowa miernikow agregatowych do oceny poziomu rozwoju spoleczno-gospodarczego. [Construction of Aggregate Measures for the Assessment of the Level of Socio-Economic Development], Scientific Journal of Warsaw University of Life Sciences, Economics and Organization of Agri-Food Sector, no. 74, Warsaw.

5. Krok - Czyz K., Tomaszewski P., Wysocka M., Zembaty M. (2009), Analiza listy wskaznikow bazowych w ramach Regionalnego Programu Operacyjnego Wojewodztwa Lubelskiego na lata 2007-2013. [Analysis of the List of Baseline Indicators within the Framework of the Regional Operational Program of the Lubelskie Voivodeship for the Years 2007-2013], Warsaw-Wroclaw.

6. Wojcik M. (2014), Strategia rozwoju wojewodztwa jako instrument rozwoju regionalnego na przykladzie wojewodztwa swietokrzyskiego. [Voivodship Development Strategy as an Instrument of Regional Development on the Example of the Swietokrzyskie Voivodeship], Studies and Materials, Miscellanea Oeconomicae, no. 3, Kielce.

7. Szewczuk A., Kogut-Jaworska M., Ziolo M. (2001), Rozwoj lokalny i regionalny. Teoria i praktyka [Local and Regional Development. Theory and Practice], Published by C.H. Beck, Warsaw.

8. Wozniak D. (2005), Modele polityki rozwoju regionalnego a konkurencyjnosc wojewodztwa na przykladzie wojewodztwa malopolskiego. [Models of Regional Development Policy and Competitiveness of a Voivodeship on the Example of the Małopolska Voivodeship], Cracow University of Economics, Cracow (doctoral dissertation). 